\title{
Research on the Current Situation of Dragon Dance and Lion Dance in
}

\section{Southern Sichuan}

\author{
Yudong Tang ${ }^{1, a}$, Tao Shou ${ }^{2, b}$ \\ 1. Neijiang Normal University, Sichuan, Neijing, 641100 , \\ 2. Taian Yingxiongshan Middle School, Shandong, Taian, 271000 \\ a email, ${ }^{b}$ email
}

\begin{abstract}
Key words: Southern Sichuan,Dragon dance and lion dance,Dulture,Current situation research
\end{abstract}
\begin{abstract}
Southern Sichuan occupies a decisive role in economic and cultural life of Sichuan Province. Southern Sichuan has profound cultural deposits and national cultural life there is rich and colorful. However, social development proposes challenges to the protection and inheritance of traditional culture in Southern Sichuan, which causes the awkward situation that dragon dance and lion dance with traditional cultural characteristics in Southern Sichuan have no vacant succession and might fail to be handed down from past generations. This paper adopts document literature method, field method, expert interview method, logical analysis and so on for analysis and researches on the situation of dragon dance and lion dance activities in Southern Sichuan. The conclusion is that dragon dance and lion dance in Southern Sichuan are rich and colorful with unique characteristics. The inheritance and development of dragon dance and lion dance must change trains of thought and form effective economic exploitation points so as to form benign circulation. In the meantime, government guidance should be enhanced and social attention should be strengthened. Cooperation with schools should also be strengthened so as to cultivate professional talents.
\end{abstract}

\section{Introduction}

Dragon dance and lion dance are Chinese traditional forms of physical training and they contain profound Chinese traditional culture. In the 5000 years of historical development of Chinese nation, they have played important roles. Their development has profound and mysterious colors and is closely combined with social activities, such as sacrifice, religion, festivals, etc. In Sichuan, dragon dance is very popular as a folk activity of sacrifice and praying for rain, and the content is very rich and colorful with numerous types. Panlong Song was first popular in Zigong area and there were some recordings about dragon dance. For example, "dragon lanterns originated from the Tang Dynasty and gongs and drums sprang up in the Song Dynasty”. ${ }^{[1]}$ Recordings about dragons dance are quite few. The representative lion dance in Southern Sichuan does not have a long history and it was carried out at the end of the Qing Dynasty. Dragon dance and lion dance in various regions of Southern Sichuan have their own characteristics and fixed technical movements and routines that are popular among audiences have formed. Dragon dance and lion dance have strong performance function and when dragon dance and lion dance activities are carried out in the folk, the audiences have high enthusiasm in participation, which forms strong advantage for the inheritance and development of dragon dance and lion dance. However, because of the impact of modern social life, inheritance and development of dragon dance and lion dance, which have traditional 
cultural colors, have met up with quite a lot of difficulties. This project carries out investigations and researches on the current situation of the development of dragon dance and lion dance in Southern Sichuan and it analyzes the problems, thereby providing theoretical support for the launching of dragon dance and lion dance in Southern Sichuan.

\section{Research object and method}

This paper takes the inheritors of dragon dance and lion dance in Southern Sichuan and relative staff in various Sport Councils as research objects.

This thesis has looked up to about 30 pieces of papers about dragon dance and lion dance in full-text database from CNKI and the author has borrowed relative books such as Dragon Dance Course,Lion Dance Course, Chinese Dragon Dance and Lion Dance, etc., thereby accumulating large quantities of theoretical knowledge about dragon dance and lion dance and providing solid theoretical basis for the writing of the thesis.

The author has paid visits to senior artists and inheritors of dragon dance and lion dance in Southern Sichuan as well as administrative staff of various Sport Councils, consulting problems about dragon dance and lion dance.

The author organizes and processes the collected data through logical analysis method, thereby increasing persuasion and credibility of relative materials.

Through field method, the author has achieved large quantities of real and effective materials, thereby providing sufficient basis for the writing of the thesis.

\section{Status analysis of dragon dance and lion dance culture in Southern Sichuan}

Southern Sichuan in this thesis mainly includes Neijiang, Zigong, Yibin, Luzhou as well as the southern area of Leshan. The economy in these city agglomerations develops similarly and they have similar national customs with lots of common points. With the exploration and protection on national traditional sports items in various counties, regions and cities, dragon dance and lion dance activities in several cities of Southern Sichuan have developed greatly. Quite a lot of dragon dance and lion dance items with local characteristics have been listed as provincial intangible cultural heritage and even national intangible cultural heritage.

Through investigations, though dragon dance and lion dance are both Chinese traditional sports cultural items, dragon dance can be carried out more easily than lion dance in Southern Sichuan generally. The types are quite many with local characteristics and there are huge differences among various cities. The following are the statistic tables of dragon dance and lion dance in Southern Sichuan. From Table 1 and Table 2, we can see the different degrees of the two traditional sports item.

Table 1 Statistical table of dragon dance in Southern Sichuan

\begin{tabular}{|c|c|c|c|}
\hline $\begin{array}{ll}\text { Name } & \text { of } \\
\text { prefecture-level city } & \end{array}$ & County, city, region & Item & Notes \\
\hline Neijiang & $\begin{array}{l}\text { Shuangfeng Town, } \\
\text { Longchang County }\end{array}$ & $\begin{array}{l}\text { Double phoenix } \\
\text { dragon }\end{array}$ & $\begin{array}{l}\text { Provincial intangible cultural } \\
\text { heritage }\end{array}$ \\
\hline Neijiang & $\begin{array}{l}\text { Xinyuan Town, } \\
\text { ongchang County }\end{array}$ & $\begin{array}{l}\text { Nine } \quad \text { knob } \\
\text { dragon }\end{array}$ & $\begin{array}{l}\text { County-level intangible cultural } \\
\text { heritage }\end{array}$ \\
\hline Neijiang & Beimu Town & $\begin{array}{l}\text { Performance } \\
\text { dragon }\end{array}$ & \\
\hline Neijiang & $\begin{array}{l}\text { Yongxing Town, } \\
\text { Dongxing District }\end{array}$ & $\begin{array}{l}\text { Yongdong fire } \\
\text { dragon }\end{array}$ & $\begin{array}{l}\text { Dongxing District intangible } \\
\text { cultural heritage }\end{array}$ \\
\hline Zigong & Wubao Town & Grass bundle & Provincial intangible cultural \\
\hline
\end{tabular}




\begin{tabular}{|c|c|c|c|c|c|c|}
\hline \multirow[b]{2}{*}{ Zigong } & \multirow{2}{*}{\multicolumn{3}{|c|}{$\begin{array}{l}\text { Aiye Town, Gongjing } \\
\text { District }\end{array}$}} & dragon & \multirow{2}{*}{\multicolumn{2}{|c|}{ heritage }} \\
\hline & & & & Dragon lantern & & \\
\hline Yibin & \multicolumn{3}{|l|}{ Li Village } & Grass dragon & $\begin{array}{l}\text { Provincial intangible } \\
\text { heritage }\end{array}$ & cultural \\
\hline Yibin & \multicolumn{3}{|c|}{ Xingwen County } & $\begin{array}{l}\text { Performance } \\
\text { dragon }\end{array}$ & & \\
\hline Yibin & \multicolumn{3}{|c|}{ Cuiping District } & $\begin{array}{l}\text { Performance } \\
\text { dragon }\end{array}$ & & \\
\hline Yibin & \multicolumn{3}{|c|}{ Changning Country } & $\begin{array}{l}\text { Burning dragon } \\
\text { lanterns }\end{array}$ & & \\
\hline Luzhou & $\begin{array}{l}\text { Tianxing } \\
\text { County }\end{array}$ & own, & $\mathrm{Lu}$ & Grass dragon & & \\
\hline Luzhou & $\begin{array}{l}\text { Niutan } \quad \mathrm{Tc} \\
\text { County }\end{array}$ & wh, & $\mathrm{Lu}$ & Lotus dragon & \multicolumn{2}{|c|}{$\begin{array}{l}\text { County-level intangible cultural } \\
\text { heritage }\end{array}$} \\
\hline Luzhou & $\begin{array}{l}\text { Xuantan } \quad \mathrm{T} \\
\text { County }\end{array}$ & own, & $\mathrm{Lu}$ & $\begin{array}{l}\text { Heaven and } \\
\text { earth dragon }\end{array}$ & & \\
\hline Luzhou & $\begin{array}{l}\text { Yunjin } \quad \mathrm{Tc} \\
\text { County }\end{array}$ & wn, & $\mathrm{Lu}$ & $\begin{array}{l}\text { Affectionate } \\
\text { dragon }\end{array}$ & & \\
\hline Luzhou & $\begin{array}{l}\text { Tianxing } \\
\text { County }\end{array}$ & own, & $\mathrm{Lu}$ & Grass dragon & $\begin{array}{l}\text { City-level intangible } \\
\text { heritage }\end{array}$ & cultural \\
\hline Luzhou & $\begin{array}{l}\text { Fenshuiling } \\
\text { Jiangyang Di }\end{array}$ & trict & wn, & $\begin{array}{l}\text { Burning fire } \\
\text { dragon }\end{array}$ & $\begin{array}{l}\text { Provincial intangible } \\
\text { heritage }\end{array}$ & cultural \\
\hline Luzhou & Yutan Village & & & $\begin{array}{l}\text { Rain altar } \\
\text { colored dragon }\end{array}$ & $\begin{array}{l}\text { National intangible } \\
\text { heritage }\end{array}$ & cultural \\
\hline Luzhou & Bailu Town & & & $\begin{array}{l}\text { Vitex negundo } \\
\text { dragon }\end{array}$ & & \\
\hline Leshan & $\begin{array}{l}\text { Fuxi Town, } \\
\text { City }\end{array}$ & Emei & shan & Grass dragon & $\begin{array}{l}\text { Provincial intangible } \\
\text { heritage }\end{array}$ & cultural \\
\hline Leshan & Mabian & & & $\begin{array}{l}\text { Performance } \\
\text { dragon }\end{array}$ & & \\
\hline Leshan & Muchuan Co & inty & & Grass dragon & $\begin{array}{l}\text { National } \\
\text { heritage }\end{array}$ & cultural \\
\hline
\end{tabular}

From the above two tables, we can see that dragon dance and lion dance are carried out in several cities of Southern Sichuan and lion dance in Southern Sichuan is mostly southern lion. Sometimes, lion dance is performed on the same stage with dragon dance. However, it can be seen that the scope of dragon dance is larger than that of lion dance, which might because of Chinese people's worship of dragon. Though lions are also the symbol of power and wealth in Chinese people's heart, it is far from the weight of dragon in people's heart. Also, because of Sichuan region's demands for some traditional customs such as religions, sacrifice and praying for rain, the launching of dragon dance is smoother than that of lion dance; it is more popular among audiences and is more acceptable among audiences.

Dragon dance and lion dance in various cities of Southern Sichuan have been handed down to the present and there are various legends and myths with dense mysterious colors. It is because in feudal society, people could not explain some natural phenomena, so they could only create a psychological trust 
and consumed that some phenomena were controlled by gods. It was because of this trust that various legends were created, which also caused different sources of dragon dance and lion dance in various regions.

Table 2 Table of the source of dragon dance in Southern Sichuan

\begin{tabular}{lrl}
\hline Name & Source \\
\hline "Double phoenix & $\begin{array}{l}\text { It originated from the Tang Dynasty, when people in Double Phoenix believed that } \\
\text { dragon" }\end{array}$ in & dragon was a mysterious thing. It could fly to the sky, penetrate to the earth, drive \\
Shuangfeng & Town, & out evil spirits, obliterate the evil and emerge victorious in every battle. Therefore, \\
Longchang & County, & people in Double Phoenix began to center around Grass Dragon and play dragon \\
Neijiang & & dance with family as basic unit. \\
"Nine & knob
\end{tabular}

dragon” in Xinyuan According to the legend, shortly after the establishment of the town, a giant dragon

Town, Longchang, often came to make trouble and cause flood; later, it was hacked by lighting to nine Neijiang knobs. Later, people began to use bamboo splits to make nine knob dragons. They used gongs and drums to replace thunder and used fireworks to replace lighting. Then they chased the nine knob dragon and burned it. From then on, it evolved to a convention_—burning nine knob dragons.

"Yongdong fire
dragon"
Yongxing,

Dongxing District, Neijiang

"Grass bundle dragon" in Wubao Town, Zigong

“Grass dragon” in Li Village of Yibin

It originated from the fair of Yongdong Town at the end of the Ming Dynasty and the beginning of the Qing Dynasty. At that time, the most popular performance at the fair was the night "fire dragon". Later, after times of evolution, it was spread to the present.

"Grass bundle dragon" originated from the age of Zhongzong age of Tang Dynasty. Originally, children used straws to knit long braids just like the braids of women. When they installed the braids on a bamboo and waved them high, they were just like dragons, so they were called "Grass bundle dragon”. Later, when drought happened, people would wave the grass dragons to pray for rains, so they evolved to "Grass bundle dragon" and were handed down to the present.

It originated from the legend of Wei Zheng in Tang Dynasty beheading a sinful dragon in his dream. When the dragon was beheaded, the magistrate in Nanxi especially ordered Li Village to make a striking dragon to celebrate that the dragon fell to Nanxi. In old days, "gold" was the symbol of imperial power and ordinary people were not allowed to use yellow. Therefore, the smart Li villagers used the color of the straws to taunt the authority of feudal dynasty, which manifested the wisdom of Li villagers. They also burnt the grass dragon after the dance to show their contempt on feudal dynasty. From then on, grass dragon dance has been handed down from generation to generation.

"Burning fire It originated during the reign of Tongzhi in the Qing Dynasty and has been dragon” in Fenshuiling Village, Jiangyang District, Luzhou inherited for over 150 years in Fenshuiling Village. It came into birth mainly because people believed that fire dragon dance could be used to pray and remove ill fortune. People burned large numbers of firecrackers, fireworks and crackers to pray for good weather for the crops, prosperous country and peaceful life. 
"Colored dragon in

Yutan” in Yutan There had been the convention of setting an alter to pray for good weather for the Village, Luzhou crops and good harvest in Yutan Village since ancient times, and from there Yutan Village got its name. It was most popular at the end of the Ming Dynasty and the beginning of the Qing Dynasty. In the $18^{\text {th }}$ year of Guangxu, Qing Dynasty, local artists changed the original "Grass bundle dragon" to colored dragon. In 1919, the first Yutan colored dragon appeared. From then on, whenever there is marriage or funeral, local people would play colored dragon dance.

"Huangjing Huangjing dragon is a special dragon lantern that has been inherited in Bailu Town dragon” in Bailu for thousands of years. People used this method to pray for pray for good weather Town, Luzhou for the crops and good harvest.

\section{Conclusion}

Dragon dance and lion dance in Southern Sichuan have profound historical sediment, but the current project inheritance was not carried out well. There are only a few inheritors and some characteristic dragon dance and lion dance are facing the awkward situation of being lost. At present, theoretical researches of dragon dance and lion dance in Southern Sichuan are quite few, so special agencies are needed for cultural inheritance and protection to strengthen theoretical researches of dragon dance and lion dance. Though dragon dance and lion dance in Southern Sichuan have their own features and local national cultural characteristic as well as strong attraction, the inheritance and protection of dragon dance and lion dance at present is not enough. Therefore, the government should exert its post functions, increase publicity forces, create conditions to present the charm of dragon dance and lion dance and set up special agencies so as to promote the inheritance and protection of dragon dance and lion dance.

\section{Acknowledgement}

Introduction to the project: Scientific research project of Sichuan Education Department, Item number: $15 S B 0145$

\section{References}

[1]. S.J. Lv. Course of Dragon Dance [M]. Being Sport University Press, 2008.1 (In Chinese )

[2]. L. Ying and C.G. Li. Development Research of Dragon Dance and Lion Dance Folk Sport in Sichuan [J]. Tian Fu Xin Lun. 2012-06 (In Chinese )

[3]. W. Zhang. Status Survey of High-pole Lion Dance in Tangba, Yibin, Sichuan and Countermeasures Study [D]. Chengdu Sport University. 2015-06 (In Chinese )

[4]. Q.H. Shang. Cultural Trace of Lion Dance [J]. Nanjing Institute of Physical Education and Sport Journal (Social Sciences), 2004, 06:183-184. (In Chinese )

[5]. Y.S. Huang. Source and Development of Chinese Lion Dance [J]. Sport Literature and History, 2000, 01:45-46. (In Chinese )

[6]. Q.W. Duan. Historical and Cultural Sources of Chinese Dragon Dance and Lion Dance and International Communication [J]. Guangzhou Sport University Journal, 2006,05:109-111. (In Chinese )

[7]. S. J. Lv. Exploration of Folk Lion Dance and Traditional Chinese Culture [J]. Being Sport University 
Journal, 2008, 10 (In Chinese )

[8]. M. Hu. Researches on the Current Situation and Development of Chongqing Tongliang Dragon Dance [D]. Southwest University, 2008. (In Chinese )

[9]. Y.C. Chao. Researches on the Current Situation and Development of Chinese Dragon Dance and Lion Dance in Eastern Hubei [J]. Education for Chinese After-school (theory) 2011-04 (In Chinese ) 